\title{
Vegetation history of Eastern Ladoga region (Russia) during the Holocene based on pollen study of Piskarskoe Lake sediment core
}

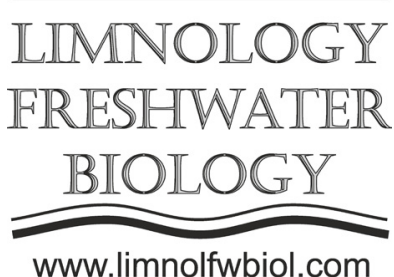

www.limnolfwbiol.com

\begin{abstract}
Gornov D.A.
Saint-Petersburg State University, Universitetskaya Emb., 7-9, Saint-Petersburg, 199034, Russia

ABSTRACT. The Onega-Ladoga isthmus is a relatively poorly studied part of the Northwestern Russia in terms of palaeo palynology. However, this area is a very important for understanding of human colonization of the Karelia Region. In addition, archaeological sites, beginning from the end of the Paleolithic, have been discovered here. This allows us to trace the human impact on the environment for the past 10,000 years. It found that the vegetation around of Lake Piskarskoe several times changed from cold-loving to warm-loving, and from hygrophytic to mesophytic. A Piskarskoe wetland began to form as a bog at the end of the Atlantic period while the maximum swamping rates happened in the Subatlantic period. As the lake is placed in a hard-reached area, there were not any anthropogenic indicators in spectra. This requires a detailed multimethod study of the core to define indicators of anthropogenic impact.
\end{abstract}

Keywords: pollen analysis; Lakes Piskarskoe; Onega; Ladoga; Onega-Ladoga isthmus; human impact

\section{Introduction}

The Onega-Ladoga isthmus is a relatively poorly studied part of the Northwestern Russia in terms of palaeopalynology. However, it is interesting to determine the vegetation invasions on the Southern Karelia after the last glaciation. In addition, archaeological sites, starting from the end of the Paleolithic, have been discovered here. This allows us to trace the human impact on the environment over the past 10,000 years. Thus, the aims of the work are: (1) reconstruction of vegetation changes in the Holocene based on pollen analysis of Piskarskoe lake sediments; and (2) definition of human impact indicators in pollen spectra.

\section{Materials and methods}

In the summer of 2013, the drill core was obtained from Lake Piskarskoe by the Saint-Petersburg Complex Geological Expedition (led by A.A. Potapovich). The core was long $6.8 \mathrm{~m}$. The depth of the lake at the drilling site was $2.5 \mathrm{~m}$. Core sediments were studied by pollen analysis with sample interval $10 \mathrm{~cm}$ (total number 70 samples). Samples were processed according to the method of V.P. Grichuk (Grichuk, Zaklinskaya, 1948) Temporary preparations were examined with a LaboMed-1 microscope version 3 with magnification of 400 times. Pollen diagram was made with the TiliaGraph software. There was obtained a radiocarbon age for the sample from depth of 8.9-9.3 m, which amounted to $9560 \pm 210$ non-calibrated years (LU-6987).

Piskarskoe lake is located on the Onega-Ladoga isthmus (in the east of the Leningrad Region, $3 \mathrm{~km}$ to the west from Lodeynoe Pole town), in the northern part of the oligotrophic wetland of the same name, located on the left bank of the Svir river Valley. The lake has the following morphometric parameters: width $\sim 500 \mathrm{~m}$, length $\sim 220 \mathrm{~m}$, average depth $\sim 2 \mathrm{~m}$. It is surrounded by typical high bog vegetation: Sphagnum mosses, haircap mosses, sundews, cotton-grasses, sedges, cranberries, blueberries, blueberries, lingonberries, Labrador teas, dwarf birches, Scots pines. Alders and spruce forests also grow in several kilometers from the investigated lake.

\section{Results}

A diagram was constructed, based on the results of pollen analysis. In which, according to the main dominants of pollen spectra, were identified 9 palynozones. Palynozone 1 is characterized by the predominance of Pinus (20.9\%), Betula (29.6\%) and Cyperaceae $(43.5 \%)$ pollen. Palynozone 2 is characterized by a sharp decrease in the role of Cyperaceae pollen with a simultaneous increase in the number of Pinus (41.2\%) and Betula (67.9\%) pollen. Pollen zone 3 is characterized by a sharp increase in 
the proportions of Picea (2.7\%), Corylus (1.3\%) and Alnus (4.3\%) pollen; the ratio of other taxa did not change. Palynozone 4 is characterized by a decrease in the proportion of Corylus pollen $(0.3 \%)$ and the appearance of pollen from broad-leaved tree species. In the palynozone 5 maximum pollen levels were found for Quercus (1.1\%), Ulmus (4.8\%), and Tilia $(0.9 \%)$. Decrease in the share of Corylus pollen and broad-leaved tree species are noted for palynozone 6 spectra. The role of Picea (2.4\%) and Salix (0.5\%) pollen decreases and the number of pollen of Pinus (39.6\%), Betula (50.2\%), Alnus (9.3\%), and Poaceae $(2.9 \%)$ pollen increases in the spectra of palynozone 7. Palynozone 8 is distinguished by a sharp increase in the amount of Picea pollen (13.9\%), a decrease of Alnus pollen number $(6.6 \%)$, and a decrease in Salix pollen content $(0.3 \%)$. An increase in the amount of pollen from Betula (46.8\%), Pinus (39.9\%), Poaceae (1.2\%), and Cyperaceae $(5.5 \%)$ is noticeable in the palynozone 9. A clear peak of Picea (17.0\%) and Salix (0.6\%) pollen stands out. The onset of the palynozone is characterized by a sharp increase in the number of Sphagnum spores in the pollen spectra.

\section{Discussions}

The content of the palynozone 1 pollen spectra may indicate relatively cool and humid environmental conditions at the time of the beginning of the sedimentation, when swamp landscapes dominated in the surrounding area. When spruce-pine-birch forests with alder and willow trees started to grow above the section (palynozone 2), conditions became favorable for the propagation of vegetation less demanding to environmental conditions. This phenomenon is characterized by a change in the dominants: for example, Picea and Alnus were replaced by Pinus and Betula. This situation may indicate a change in the water regime of soils in the vicinity of the Piskarskoe lake. Further along the section (palynozone 3), natural conditions became similar to palynozone 1. During the formation of palynozone 4 pollen spectra, climatic conditions were somewhat warmer than modern ones. It caused the appearance of broad-leaved vegetation. Subsequently (palynozone 5) is characterized by the most widespread of warm-loving broad-leaved species of trees and shrubs, as well as nemoral herbs. This picture indicates even warmer and more favorable climatic conditions. Further (palynozone 6) there were changes in the direction of cooling. This is confirmed by a sharp decrease of the role of broad-leaved trees and grasses pollen in the spectra. There is a local increase in the amount of Ulmus pollen in palynozone 7 spectra. This phenomenon indicates an increase of soil moisture in the study area at this time. But, in the palynozone 8, which replaced it, the role of Ulmus pollen in the the spectra formation sharply decreased. At the same time the increased role of Picea, Alnus, and Poaceae pollen shows the establishment of cooler and wetter environmental conditions. The role of Betula and Pinus pollen becomes more prominent in palynozone 9 . Such pollen spectra characterize the modern vegetation cover of the Eastern part of the Leningrad region. The local maxima of Picea and Salix pollen probably describe the surrounding vegetation, while there are some spruce forests and alders - indicators of waterlogged areas. Approximately from the middle of palynozone 5 the appearance and gradual growth of the number of Sphagnum spores can be noted that means bogging of the lake.

Dedicated to the radiocarbon dating and to the pollen spectra, it can be assumed that palynozone 1 corresponds to the $\mathrm{PB}$ stage of the Holocene, palynozone 2 to $\mathrm{BO}$, palynozone 3 to AT1, palynozone 4 to AT2, palynozone 5 to AT3, palynozone 6 to SB1, palynozone 7 is SB2, palynozone 8 is SB3, and palynozone 9 is SA, according to the Blytt-Sernander scheme.

According to the previous palaeopalynological researches in the Onega-Ladoga isthmus territory (Elina et al., 2010; Vorobyeva et al., 2017; Savelieva et al., 2019) it can be assumed that pollen spectra from Piskarskoe lake generally correlate them, excluding some local features like growth of Sphagnum spores number; Picea and Salix pollen local peaks in the uppermost layers.

There was not found any evident connection between pollen spectra changes and human impact - this can be explained by the fact that the main occupation for ancient people in Southern Karelia was fishery and all settlements were situated near lakes and water streams (Melnikov, German, 2013; Kochkurkina, 2003). Piskarskoe lake is quite far from the Svir river and is surrounded by wetlands, so the anthropogenic impact on the vegetation was rather weak.

\section{Conclusions}

Based on the obtained materials, it can be concluded that during the Holocene, the vegetation in the vicinity of the Piskarskoe lake changed several times from cold-loving to warm-loving, from hygrophytic to mesophytic. The Piskarskoe wetland began to form as a Sphagnum-type bog at the end of the Atlantic period, while the maximum swamping rates were noted in the Subatlantic period. As the lake is placed in a hardreached area, additional more detailed study of the core is required to define indicators of anthropogenic impact.

\section{Acknowledgements.}

Author is highly grateful to the scientific supervisor, Dr. L.A. Savelieva for help and comments during the analytical part and writing. I also want to thank Dr. M.V. Shitov for collecting the material and allowing me to study it.

\section{References}

Elina G.A., Lukashov A.D., Yurkovskaya T.K. 2010. Late Glacial and Holocene palaeovegetation and palaeogeography of Eastern Fennoscandia. The Finnish Environment, Issue 4, Helsinki: Finnish Environment Institute. 
Grichuk V.P., Zaklinskaya E.D. 1948. Analysis of fossil pollen and spores and its application in paleogeography, Moscow: OGIZ. (in Russian)

Kochkurkina S.I. 2003. Historical and archaeological sites in Onega-Ladoga water catchment. "Ryabinin readings", Kizhi historical site - Petrozavodsk. (in Russian)

Melnikov I.V., German K.E. 2013. Ancient settlements in the southern Zaonezhye (Mesolithic - Aeneolithic), Kizhi historical site - Petrozavodsk. (in Russian)

Savelieva L.A., Andreev A.A., Gromig R., et al. 2019. Vegetation and climate changes in northwestern Russia during the Lateglacial and Holocene inferred from the Lake Ladoga pollen record. Boreas 48: 349-360. https://doi.org/10.1111/ bor.12376. ISSN 0300-9483.

Vorobyeva A.V., Gladysheva A.S., Potapovich A.A., Ryumin A.G. 2017. Paleolimnology of small lakes in the middle flow of Svir river: new data on the natural environment development at the end of the Pleistocene and in the Holocene. Proceedings of the 5th International Conference of Young Scientists and Specialists in Memory of Academician A. P. Karpinsky (February 28 - March 3, 2017, VSEGEI, St. Petersburg). The Ministry of Natural Resources of Russia, Rosnedra, VSEGEI. SPb.: VSEGEI Publishing House, 31-34 pp. (in Russian) 